\title{
Advances in the knowledge of the metabolism of vitamin D
}

\section{By D. R. Fraser, Dunn Nutritional Laboratory, University of Cambridge and Medical Research Council, Cambridge $\mathrm{CB}_{4} \mathrm{IXY}$}

The secosteroid, vitamin $\mathrm{D}$, functions in calcium homoeostasis as a hydroxylated derivative: 1,25-dihydroxy-vitamin $\mathrm{D}(1,25-\mathrm{DOHD})$. This molecule becomes localized in the nuclei of the mucosal cells of the small intestine (Lawson, Wilson \& Kodicek, I969) where it appears to induce messenger RNA (Emtage, Lawson \& Kodicek, I973) for proteins which will subsequently increase the transport of $\mathrm{Ca}$ by these cells. Thus vitamin $\mathrm{D}$ seems to act in a manner similar to the classical steroid hormones of the adrenal cortex and the gonads.

It is notable that the steroid hormones all have oxygen functions at the extremities of the long axis of the molecule. For example, corticosterone, cortisol and aldosterone have 3 -keto- and $2 \mathrm{I}$-hydroxy-groups while progesterone has ketogroups on both $\mathrm{C}-3$ and $\mathrm{C}-20$. This polar oxygenation enables these steroids to interact, with high affinity, with specific receptor proteins in target cells. The specificity of the interaction is enhanced by the presence of functional groups deployed elsewhere on the steroid structure. In the instance of $1,25-\mathrm{DOHD}$ the polar oxygens are the hydroxy-groups on $\mathrm{C}-3$ and -25 and the group giving the functional specificity is the hydroxyl on $\mathrm{C}-\mathrm{I}$.

\section{The hydroxylation of vitamin $D$}

Conversion of vitamin $D$ to its functional state takes place in two stages: 25 hydroxylation in the liver (Ponchon, Kennan \& DeLuca, 1969) followed by Ihydroxylation in the kidney (Fraser \& Kodicek, 1970). Hence vitamin D derived from the environment, either as the preformed vitamin in the diet or as a product of the ultraviolet irradiation of 7 -dehydrocholesterol in skin tissue, is transported in the blood to the liver, where some of it is metabolized to 25 -hydroxy-vitamin D (25-OHD). This reaction occurs in the endoplasmic reticulum of liver cells (Bhattacharyya \& DeLuca, 1974) and the modified molecule is secreted back into the circulation, where in most mammals it is carried on a specific $\alpha$-globulin protein (Edelstein, 1974). The hydroxylation of 25-OHD at C-1 takes place in the mitochondria of kidney cells (Fraser \& Kodicek, 1970) and the dihydroxylated derivative passes back into the blood, from which it is removed by cells of the target tissues: the small intestine, bone and the kidney itself.

Since the discovery of this metabolic sequence, the hydroxylation of vitamin $D$ has come to be regarded as an activating process to change a 'biologically inert' 


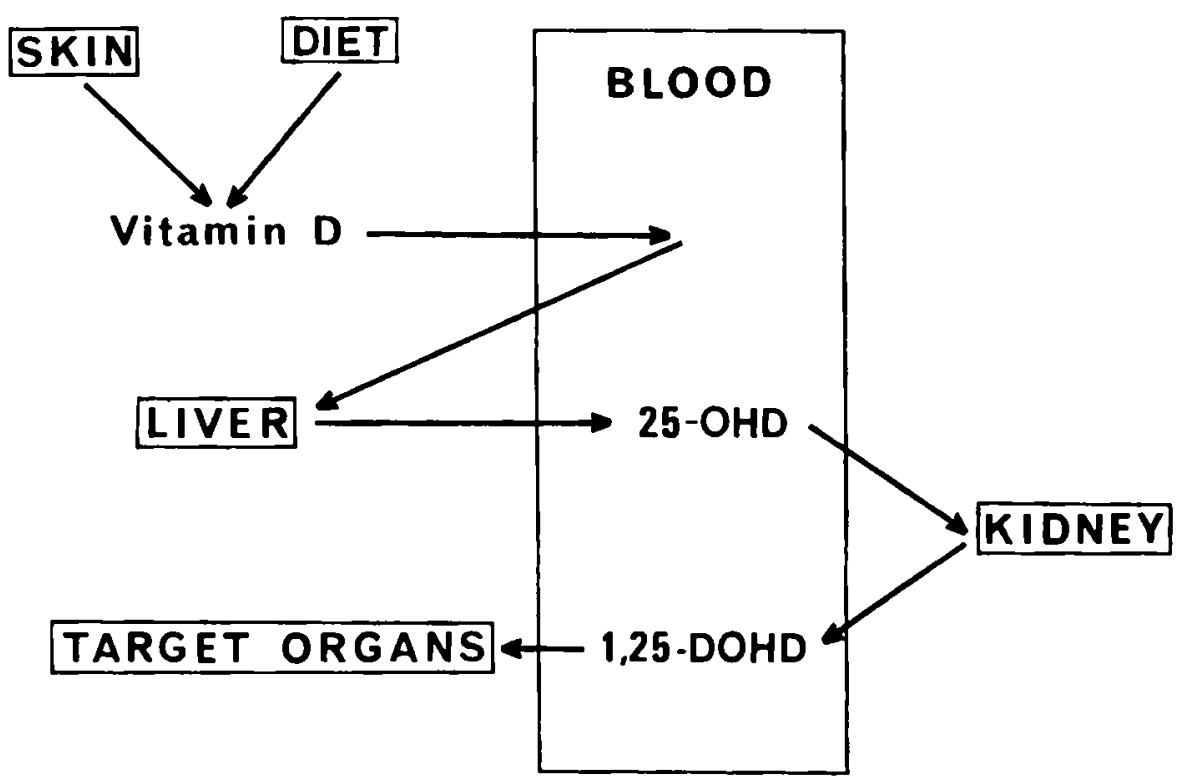

Fig. I. Scheme for the metabolism of vitamin $\mathrm{D}$ in relation to its function in the maintenance of the extracellular calcium concentration; 25-OHD, 25-hydroxy-vitamin D; 1,25-DOHD, 1,25-dihydroxyvitamin D.

molecule into a completed and now functional form. It is as if vitamin D were a metabolizable nutritional substrate requiring modification in the manner, for example, of the vitamin pyridoxine, which is converted to pyridoxal phosphate, the active coenzyme form. There is, however, a difference in these types of intermediary reactions. Because the function of vitamin $\mathrm{D}$ is to regulate $\mathrm{Ca}$ metabolism, the formation of the active molecule, $1,25-\mathrm{DOHD}$, must itself be regulated according to the requirements for maintaining $\mathrm{Ca}$ homoeostasis.

\section{Regulation of the hydroxylation of vitamin $D$}

After the administration of a single dose of vitamin $\mathrm{D}$ to man, the rat or the chicken, it has been demonstrated in many laboratories that, with time, the plasma concentration of the vitamin falls rapidly in comparison with that of its product 25 -OHD. Thus with the usual low intake of vitamin D the major vitamin D substance in plasma is $25-\mathrm{OHD}$. The plasma can therefore be considered to be the body store of substrate for the formation of the active metabolite, 1,25-DOHD. The concentration of $25-\mathrm{OHD}$ in plasma is related to the input of vitamin D and its production does not seem to be regulated according to need. Hence the higher the intake of vitamin D, the greater will be the concentration of 25-OHD in plasma. This can be shown experimentally in vitamin D-deficient chickens given varying doses of cholecalciferol (Table $\mathrm{s}$ ): $36 \mathrm{~h}$ after a dose of $5 \mathrm{mg}$ cholecalciferol 
the plasma 25 -hydroxycholecalciferol $(25-\mathrm{HCC})$ level has risen to over $100 \mu \mathrm{g} / 1$ and the cholecalciferol level itself is nearly five times greater again.

Table 1. Concentrations of cholecalciferol and 25-hydroxycholecalciferol (25$H C C)$ in plasma of 3-week-old, vitamin D-deficient chickens $3^{6} h$ after a subcutaneous injection of $\left[1,2-{ }^{3} \mathrm{H}\right]$ cholecalciferol"

(Values are for one chicken/dose level)

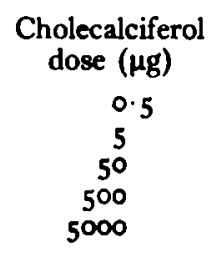

\begin{tabular}{|c|c|}
\hline \multicolumn{2}{|c|}{ Plasma concentration $(\mu \mathrm{g} / \mathrm{l})$} \\
\hline Cholecalciferol & $25-\mathrm{HCC}$ \\
\hline $\begin{array}{r}0.3 \\
6.5 \\
61 \cdot 5 \\
327 \cdot 3 \\
505 \cdot 5\end{array}$ & $\begin{array}{r}1.5 \\
12.5 \\
28.0 \\
74.8 \\
117.6\end{array}$ \\
\hline
\end{tabular}

-As a solution in propylene glycol.

On the other hand, the formation of $1,25-\mathrm{DOHD}$ is very limited. In vitamin Ddeficient chickens the concentration of $1,25-\mathrm{DOHD}$ in the intestinal mucosa following a single injection of $2.5 \mu \mathrm{g}$ cholecalciferol rises to no more than $3 \mathrm{ng} / \mathrm{g}$ (Lawson, 1971). However, the concentration in plasma of such birds is less than $300 \mathrm{ng} / \mathrm{l}$. When the activity of $25-\mathrm{HCC}-\mathrm{I}$-hydroxylase is measured in the chicken kidney, it is found to increase during the onset of vitamin D deficiency so that after 3-4 weeks the capacity to produce 1,25 -DOHD may be 20 times greater than that of normal chickens (Fraser \& Kodicek, 1973). Thus the ability to I-hydroxylate 25OHD increases according to the severity of the vitamin D deficiency, but the production of $1,25-D O H D$ cannot be raised by giving more vitamin $D$.

The 25-HCC-I-hydroxylase activity in kidney is correlated with a tendency for the extracellular Ca concentration to fall. Since r,25-DOHD causes increased intestinal absorption of $\mathrm{Ca}$ (Kodicek, Lawson \& Wilson, r970; Myrtle \& Norman, 1971; Omdahl, Holick, Suda, Tanaka \& DeLuca, 1971), mobilization of Ca from bone (Reynolds, 1974) and probably increased tubular reabsorption of $\mathrm{Ca}$ in the kidney (Puschett, Fernandez, Boyle, Gray, Omdahl \& DeLuca, 1972), then these combined actions of $1,25-\mathrm{DOHD}$, which raise the extracellular $\mathrm{Ca}_{\mathrm{a}}$ concentration, will inhibit its own production (Fig. 2). Regulation of $25-\mathrm{HCC}-\mathrm{I}$-hydroxylase is mediated primarily by a trophic action of parathyroid hormone (Garabedian, Holick, DeLuca \& Boyle, 1972; Rasmussen, Wong, Bikle \& Goodman, 1972; Fraser \& Kodicek, 1973), but it is very likely that other factors, such as the intracellular concentrations of $\mathrm{Ca}$ (Larkins, MacAuley, Rapoport, Martin, Tulloch, Byfield, Matthews \& MacIntyre, 1974) and phosphorus (Tanaka \& DeLuca, 1973), also influence the enzyme activity.

The two stages in the functional metabolism of vitamin $\mathrm{D}$ are therefore fundamentally dissimilar. The 25 -hydroxylation reaction proceeds according to the 


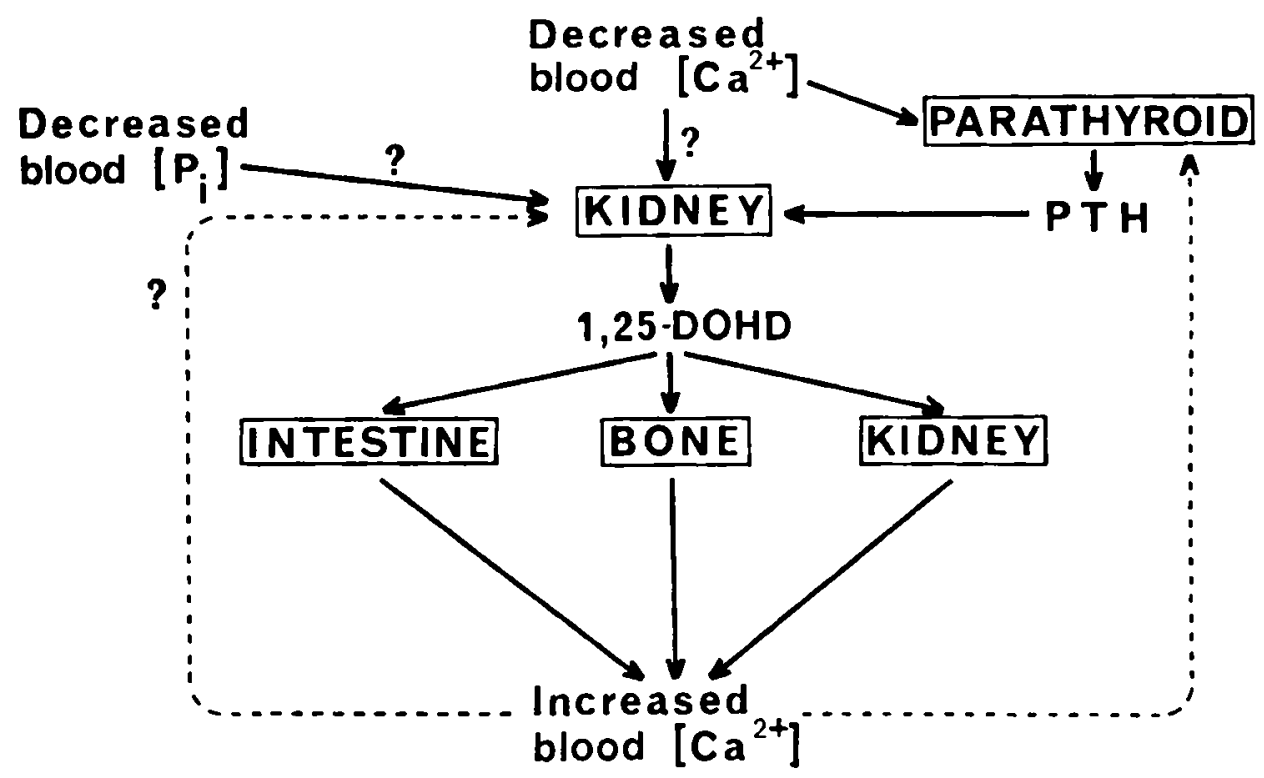

Fig. 2. Scheme for the control of 1,25-dihydroxy-vitamin D (1,25-DOHD) formation: stimulation; $\cdots \ldots \ldots$, , inhibition; $\left[\mathrm{P}_{\mathrm{i}}\right.$, inorganic phosphate concentration; $\left[\mathrm{Ca}^{2+}\right]$ calcium ion concentration; PTH, parathyroid hormone.

intake of vitamin $D$, while the $I$-hydroxylase is firmly regulated in an endocrinological system as an integral part of the $\mathrm{Ca}$ homoeostatic mechanism.

\section{Vitamin $D$ metabolism in normal animals}

Most vitamin D research has been done with vitamin D-deficient animals and has been concerned with the significance of $1,25-\mathrm{DOHD}$ in $\mathrm{Ca}$ homoeostasis. However, vitamin $\mathrm{D}$ metabolites may have a role apart from that of maintaining a constant extracellular $\mathrm{Ca}$ concentration. If chickens are given sufficient radioactively labelled cholecalciferol to enable normal growth, then the pattern of vitamin $\mathrm{D}$ metabolites can be observed in a situation where there is no stress on the Ca homoeostatic mechanism. In such chickens the 25-OHD level in plasma is about $10 \mu \mathrm{g} / \mathrm{l}$. This is $5^{-10}$ times higher than its concentration in any other tissue. The amount of $1,25-\mathrm{DOHD}$ in plasma is about 500 times less than that of 25$\mathrm{OHD}$, being about $20 \mathrm{ng} / \mathrm{l}$. Yet this concentration maintains the 1,25-DOHD in intestinal mucosa at about $0.4 \mathrm{ng} / \mathrm{g}$, which presumably is sufficient to allow adequate $\mathrm{Ca}$ absorption.

Other metabolites of vitamin $\mathrm{D}$ are also found in the plasma of these normal chickens, the most notable being 24,25 -dihydroxy-vitamin $D($ about $2 \mu \mathrm{g} / 1$ ) and 25,26-dihydroxy-vitamin $\mathrm{D}$ (about $0.7 \mu \mathrm{g} / \mathrm{l}$ ). Like 25-OHD, these dihydroxylated metabolites are more concentrated in plasma than elsewhere. It is possible that they are also concerned with $\mathrm{Ca}$ metabolism, but functions have not yet been defined for them. 


\section{REFERENCES}

Bhattacharyya, M. H. \& DeLuca, H. F. (1974). Archs Biochem. Biophys. 160, 58.

Edelstein, S. (1974). In The Metabolism and Function of Vitamin D, p. 43 [D. R. Fraser, editor] London: The Biochemical Society.

Emtage, J. S., Lawson, D. E. M. \& Kodicek, E. (1973). Nature, Lond. 246, 100.

Fraser, D. R. \& Kodicek, E. (1970). Nature, Lond. 228, 764.

Fraser, D. R. \& Kodicek, E. (1973). Nature New Biol. 241, 163.

Garabedian, M., Holick, M. F., DeLuca, H. F. \& Boyle, I. T. (1972). Proc. natn. Acad. Sci. U.S.A. 69,1673 .

Kodicek, E., Lawson, D. E. M. \& Wilson, P. W. (1970). Nature, Lond. 228, 763.

Larkins, R. G., MacAuley, S. J., Rapoport, A., Martin, T. J., Tulloch, B. R., Byfield, P. G. H., Matthews, E. W. \& MacIntyre, I. (1974). Clin. Sci. mol. Med. 46, 569.

Lawson, D. E. M. (1971). Proc. Nutr. Soc. 30, 47.

Lawson, D. E. M., Wilson, P. W. \& Kodicek, E. (1969). Nature, Lond. 222, 171.

Myrtle, J. F. \& Norman, A. W. (1971). Science, N.Y. 171, 79.

Omdahl, J., Holick, M. F., Suda, T., Tanaka, Y. \& Deluca, H. F. (1971). Biochemistry, Easton 10, 2935 .

Ponchon, G., Kennan, A. L., \& DeLuca, H. F. (1969). F. clin. Invest. 48, 2032.

Puschett, J. B., Fernandez, P. C., Boyle, I. T., Gray, R. W., Omdahl, J. L. \& DeLuca, H. F. (1972). Proc. Soc. exp. Biol. Med. 141, 379 .

Rasmussen, H., Wong, M., Bikle, D. \& Goodman, D. B. P. (1972). F. clin. Invest. 51, 2502.

Reynolds, J. J. (1974). In The Metabolism and Function of Vitamin D, p. 91 [D. R. Fraser, editor]. London: The Biochemical Society.

Tanaka, Y. \& DeLuca, H. F. (1973). Archs Biachem. Biophys. 154, 566. 